\title{
Pasteur's quadrant: an appealing ecophronetic alternative to the prevalent Bohr's quadrant in ecosystem services research
}

\author{
Wei-Ning Xiang
}

Received: 17 September 2017/ Accepted: 7 October 2017/Published online: 16 October 2017

(C) Springer Science+Business Media B.V. 2017

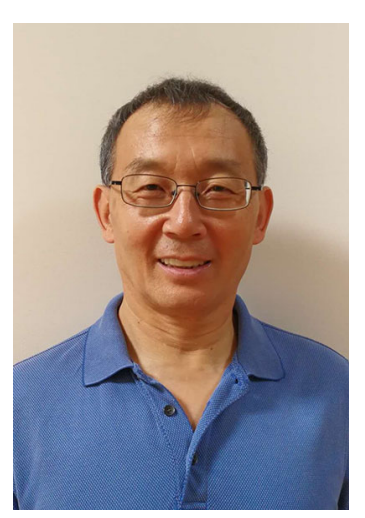

\section{A missing link and the ensuing knowledge gaps}

Since the publication of Nature's services: societal dependence on natural ecosystems (Daily 1997) and The value of the world's ecosystem services and natural capital (Costanza et al. 1997), the past two decades have witnessed the continuing production of large number of journal articles and books on

W.-N. Xiang ( $(\square)$

Center for Ecophronetic Practice Research, College of Architecture and Urban Planning, Tongji University, Shanghai 200092, China

e-mail: wxiang@uncc.edu; wnxiang@tongji.edu.cn ecosystem services (ES, thereafter) research. However, as revealed in the recent literature reviews (Albert et al. 2014; Haase et al. 2014; Hansen et al. 2015; Luederitz et al. 2015; Woodruff and BenDor 2016), the state of the ES scholarly enterprise in accomplishing its noble mission "to inform and direct" practitioners in planning and management (Egoh et al. 2008, p. 135) could have been more effective should a missing link in its scholarly inquiry be identified and rectified: while huge amount of effort was devoted to improving instrumental effectiveness and efficiency of ES valuation and mapping, little dedicated to implementing the new ES knowledge in practice (Haase et al. 2014, pp. 424-426; Woodruff and BenDor 2016, p. 91). Manifesting this hiatus, rarely in the literature did research questions like the following ever arise pertaining to the use and effects, that is, the actual practical implementation and ensuing performance, of the ES knowledge the scholarly community generated:

Was the new ES knowledge ever delivered to and accepted by the designated practical beneficiaries-planners and managers? Was it actually used in their practice? Was it effective in helping produce desirable or expected results they care about? What kind of, and how much, difference in their practice did the implementation of ES knowledge make, if at all? 
With this apparent lack of interest or even disinterest identified, it came as no surprise that there are substantial gaps in the literature on ES knowledge implementation and performance-not only few if any follow-up studies on the ES knowledge performance have ever been reported, but the majority of ES research documented in the literature and examined by Haase et al. (2014) also "included little or no information on implementation" (Haase et al. 2014, p. 425).

\section{The prevalence of Bohr's quadrant in ES research}

Why is it that a scholarly enterprise aiming to inform, influence, or even direct practitioners (Egoh et al. 2008, p. 135; Haase et al. 2014, p. 425) demonstrated so little research interest in practical implementation, and made so insignificant effort to push the envelope? One speculation, apart from those that are implicitly articulated in the literature reviews [e.g., the limited practical knowledge of institutional design and implementation processes (Haase et al. 2014, p. 426), the inadequate understanding about practitioner's needs and the lack of tested instrumental capabilities (Albert et al. 2014, p. 1278), and the mismatch in the scale of governance and management (Kremer et al. 2016, p. 4)], is that it has to do with the role members of the ES scholarly community chose to enact in conducting research, and with the stand they took toward research. This can be examined through a lens of research in socio-ecological systems where the ES scholarly community conducts its research.

\section{The Schön-Stokes model: a lens for examination}

When conducting research in the varied landscape of social practice (for example, in one or any combination of the five activities in ecological practiceplanning, design, construction, restoration and management; in education, law, or medicine), according to American philosopher and planning theorist Donald Schön, members of the scholarly community are confronted with the choice between standing on the high ground of theory and descending to the swampy lowlands of practice (Schön 2001, p. 191). The dual irony of this situation is that on the one hand, the problems of the lowlands, while being "of greatest human concern" (Ibid.), are wicked and thus less capable of, or even resistant to, scientific or technical solution; and on the other hand, the problems of the high ground, while tending "to be relatively unimportant to individuals or to society at large" (Ibid.), are tame, or can arguably be perceived to be so, lending themselves to solution through the use of scientific theory and technique (Schön 2001, p. 191; Xiang 2017 , p. x; for a recent and succinct account on wicked and tame problems in socio-ecological systems, see Xiang 2013).

For scholars who chose to stay on the high ground of theory in conducting research, there are two further choices.

They may identify themselves as scholars of pure basic research for fundamental understanding, and position in Bohr's quadrant in the Quadrant Model of Scientific Research that American political scientist Donald Stokes proposed in 1997 (Fig. 1 presents an expanded version developed in this essay that incorporates Schön's ideas above stated ${ }^{1}$; for the seminal articulation of the original model, see Stokes 1997, pp. 70-75). To enact this role, they take the stand that basic research should and can be motivated "solely by the quest for understanding (of the problems of the high ground-the author) without thought of practical use." (Ibid., p. 73) Through a research process that follows the logic of science, they strive to generate "pure, objective, and rational" knowledge (Cook and Spray 2012, p. 93) pertaining to the problems of the high ground (for a recent and succinct account on the defining characteristics and limitations of the logic of science, see Sandberg and Tsoukas 2011, pp. 340-342).

Alternatively, they may, while remaining in Bohr's quadrant, identify themselves as scholars of applied basic research. Unlike those in Edison's quadrant (Fig. 1) of pure applied research (Stokes 1997, p. 74) or action research (Smith et al. 2013, p. 152; for a comprehensive account of action research, see Stringer 2014) who are immersed in the swampy lowlands of practice conducting research that is motivated "solely by the applied goals (of problem-solving in practice-the author) without seeking a more general understanding of the phenomenon of a scientific field"

\footnotetext{
$\overline{1}$ Descriptions about the expanded model are provided as needed hereafter, as a full-scale discussion is inevitably beyond the scope of this essay and will be provided elsewhere.
} 


\begin{tabular}{l|l|l|}
\cline { 2 - 3 } $\begin{array}{l}\text { Quest for } \\
\text { fundamental } \\
\text { understanding }\end{array}$ & $\begin{array}{l}\text { Bohr's quadrant of } \\
\text { pure basic research } \\
\text { Interest in } \\
\text { problems of } \\
\text { high ground }\end{array}$ & $\begin{array}{l}\text { Pasteur's quadrant } \\
\text { research } \\
\text { of use-inspired basic } \\
\text { research for practice } \\
\text { quadrant) }\end{array}$ \\
\cline { 2 - 3 } & $\begin{array}{l}\text { Johnson's quadrant } \\
\text { of free roaming } \\
\text { (McHarg's quadrant) }\end{array}$ & $\begin{array}{l}\text { Edison's quadrant of } \\
\text { pure applied } \\
\text { research /action } \\
\text { research } \\
\text { (Li Bing's quadrant) }\end{array}$ \\
\hline
\end{tabular}

Consideration of use \&

Interest in problems of lowlands

Fig. 1 The Schön-Stokes model of research in socio-ecological systems [Stokes asserted that the lower left-hand quadrant "is not empty" (1997, p. 74), and "can be important precursors of research in Bohr's quadrant... as well as of research in Edison's quadrant." (Ibid., p. 75) He however gave no name to it. I thus take the liberty of designating it as Johnson's quadrant in honor of American history scholar Paul Johnson who made the following observation on the rambling style of research and knowledge acquisition before and during "the birth of the modern" (Johnson 1992, p. 543, italic added). "Physics and chemistry, science and engineering, literature and philosophy, art and industrial design, theory and practice-all constituted a continuum of knowledge and skill, within which men roamed freely. The notion of separate, compartmentalized 'disciplines,' later imposed by universities, did not yet exist." Designating the other three quadrants respectively with the names of American systems ecologist H.T. Odum, American ecological planner Ian McHarg, and Chinese ecological engineer Li Bing, I attempt to help readers to see the greater relevance of the Schön-Stokes model to ecological practice and research] (After Schön 2001, p. 191 and Stokes 1997, p. 73)

(Stokes 1997, p. 74), scholars of applied basic research take the stand that through a knowledge transfer process that still follows the logic of science, the pure, objective, and rational knowledge that colleagues of pure basic research generated can be made relevant to and even actionable for the solution of the problems of the lowlands (Schön 2001, pp. 192-193; Xiang 2016, p. 59). In conducting research to demonstrate or prove the practical utility of the theoretical knowledge, however, scholars of applied basic research usually have to adopt "procrustean strategies" (Schön 2001, p. 192) so that the problems in "the uncertain, subjective, and biased contexts of human understanding, social factors, and governance" (Cook and Spray 2012, p. 93) can be cut-to-fit available theories and techniques (Churchman 1967, p. B-142; Schön 2001, pp. 192-193).
Examination through the lens: the undue prevalence of Bohr's quadrant in ES research

For the untenable status quo of the ES scholarly enterprise in accomplishing the ambition to inform, influence, and direct practitioners in planning and management, the Schön-Stokes model of research in socio-ecological systems (the Schön-Stokes model, thereafter) brings to light a rarely explicated yet perhaps more plausible reason-the prevalence, arguably undue, of Bohr's quadrant in ES research. While conducting research, scholars from the ES scholarly community evidently chose, intentionally or otherwise, to position themselves in Bohr's quadrant, and to enact either of the two above articulated roles with the respective stand toward research. As such, the following findings in Haase et al. (2014, pp. 424-425) should come as no surprise for they mirror quite vividly the role choice the scholars made and stand they took.

A. Only 48 of the 217 studies examined ( $22 \%$, that is) addressed ES knowledge implementation (Haase et al. 2014, p. 424)—Suggesting that among the scholars who authored the 217 articles, only a small minority was motivated to demonstrate their interest in ES knowledge implementation and to write it up (Ibid., p. 425);

B. "Only nine (of the 48-the author) studies included more detailed recommendations (i.e., longer than one paragraph)" (Ibid., p. 424)Among those who demonstrated their interest in implementation, only a small number was motivated and able to provide substantial recommendations to practitioners, and willing to share with colleagues in the ES scholarly community;

C. Of the nine studies, "a few delivered highly technical recommendations or suggested engineering solutions" (Ibid.) - Those who made substantial recommendations were driven to seek and deliver only theoretical or technical solutions with the unstated yet take-for-granted premise that the embodied knowledge would be useful to practitioners;

D. "More often, recommendations were directed generally at land management but without specifying relevant stakeholders, plans and policies." (Ibid.)-Because of the "procrustean strategies" they were usually compelled to adopt in 
conducting research in order to "cut the situations of practice to fit available techniques" (Schön 2001, pp. 192-193), most scholars could hardly make recommendations from the study results to real-world practitioners who are in specific needs within a particular context; for the purpose of demonstrating the utility of theories generated on the high ground, they were often left no choice but formulating and using imaginative practitioners who are in speculative needs within an artificialized context instead (Sandberg and Tsoukas 2011, p. 2011);

E. "Only in three cases was it stated that the results of the study were directly communicated to stakeholders. However ... the exact form of communication was left unmentioned." (Haase et al. 2014, p. 424)—For the same reason above explicated, neither the scholars nor the real-world practitioners seemed to feel the need to do so.

It is also noteworthy that even in the recently published articles that aim to attend the implementation issue revealed by Haase et al. (2014), the prevalence of Bohr's quadrant remains persistent and is readily apparent (for example, Albert et al. 2014; MacDonald et al. 2014; Kremer et al. 2016; Langemeyer et al. 2016; Artmann et al. 2017; Baró et al. 2017 and BenDor et al. 2017, to list but a few).

\section{The Pasteur's quadrant alternative}

For those in the ES scholarly community who seek to advance beyond the status quo, there is a different role to enact with a new stand toward research - the role of scholar-practitioner with a stand of practice research in Pasteur's quadrant (Fig. 1).

A scholar-practitioner, as defined by American management scholar Ed Schein (cited in Wasserman and Kram 2009, p. 12), is a scholar who is "dedicated to generating new knowledge that is useful to practitioners." (italics added) Positioning in Pasteur's quadrant in the Schön-Stokes model (Fig. 1), scholar-practitioners are interested in problems of both lowlands and high ground, and identify themselves as scholars of "use-inspired basic research" for practice (Stokes 1997, p. 73) or simply as scholars of "practice research" (Xiang 2017, p. x). To enact this role, they necessarily and often voluntarily choose to descend from the high ground of theory to the lowlands of practice along a scholar-practitioner continuum, and take the stand that the dual ambition of producing new knowledge and influencing (instead of just informing) practice can be achieved through a process "that seeks to extend the frontiers of understanding but is also inspired by considerations of use." (Stokes 1997, p. 74; for a brief account on the scholar-practitioner continuum, see Wasserman and Kram 2009, p. 14)

Best exemplifying scholar-practitioner's role in, and their stand toward, research is the outstanding work of French microbiologist Louis Pasteur whose name Stokes used to designate the upper right-hand quadrant in his Quadrant Model of Scientific Research (see its expanded version in Fig. 1). Unlike American inventor Thomas Edison who was motivated by practical considerations and disinterested in fundamental understanding, nor like Danish physicist Neils Bohr who was exactly the opposite, Pasteur was interested in both producing new knowledge and influencing practice, and skillfully capable of fusing practice and theory into a cohesive whole in research (Stokes 1997, p. 74, Smith et al. 2013, p. 152). He developed fundamental understanding about the cause of infectious disease while conducting rigorous basic research to meet real-world practitioners' specific needs for preserving beer, cheese, and milk. The two most significant offsprings of his work, the process of Pasteurization and the intellectual field of microbiology, continue to serve the human society in the modern-day world.

Among scholar-practitioners in the use-inspired basic research for ecological practice, ecological practice research, that is, American ecological planner and educator Ian McHarg stands out for his exemplary work of generating new knowledge that is useful to both practitioners and scholars (for succinct summaries of McHarg's career and work, see Schnadelbach 2001 and Steiner 2004). As a scholarpractitioner who firmly believed in the dictum that "[n]othing is as practical as a good theory" (Steiner 2004, p. 142), McHarg engaged himself throughout his career in a rigorous quest for a socio-ecological way by which practitioners, as he envisioned, "interpret, plan, and shape our surroundings." (Ibid., p. 141) Drawing on completed practice research projects and implemented ecological plans, he advanced a first-ofits-kind approach of socio-ecological diagnosis and prescription in his 1969 groundbreaking book Design 
with Nature (Schnadelbach 2001, p. 231). It provides practitioners with a useful method, famously known as McHarg's method ever since, to pursue socio-ecologically based "compatible solutions" to the problems of modern development (Ibid.). His ideas and approach of Design with Nature (McHarg 1969), as American ecological planner and educator Fritz Steiner stated, "not only changed design and planning, but influenced fields as diverse as geography and engineering, forestry and environmental ethics, soils science and ecology. The evidence is ubiquitous." (Steiner 2004, p. 142)

\section{Pasteur's quadrant as an ecophronetic alternative}

How can members of the ES scholarly community enact the role of scholar-practitioner and take the stand of ES practice research should they choose to position themselves in Pasteur's quadrant? One strategy forward would be to emulate the ecophronetic way by which scholar-practitioners like McHarg conducted their outstanding ecological practice research in Pasteur's quadrant.

In conducting ecological practice research, according to American geographer and planning scholar Wei-Ning Xiang (2016, pp. 56-58), McHarg and many scholar-practitioners alike exhibited a distinctive form of skill that enabled them to honor their commitment to assisting real-world practitioners who were in specific knowledge needs under particular circumstances. This virtuous skill, ecophronesis, or ecological practical wisdom, is the moral improvisation capability to sustain a carefully nuanced balance between the act of following the logic of practice and that of embracing the logic of science in a particular instance of ecological practice research (Ibid., pp. 58-59; for a comparative discussion of these two distinct and often interfering logics, see Sandberg and Tsoukas 2011, pp. 339-342, p. 355). With this master skill par excellence, scholar-practitioners like McHarg became much capable of generating new knowledge that is useful to the real: not only did they advance scholarly rigorous - thorough and valid-knowledge that was also immediately relevant, actionable, and potentially efficacious to the real-world practitioners who were in specific knowledge needs under particular circumstances of ecological practice; but they also produced high caliber scholarship that is enlightening to scholars and practitioners from around the world and across generations who have interest in ecological practice research (Steiner 2004, Xiang 2014, pp. 67-68; Steiner 2016; Xiang 2016, pp. 58-59; Yang and Li 2016). Furthermore, because ecophronesis embraces inherently a transdisciplinary research capability in socio-ecological systems (Xiang 2016, pp. 58-59; for recent accounts on the critical importance of transdisciplinary research, see Head and Xiang 2016; Wu 2006), ecophronetic scholar-practitioners like McHarg were immune from the pathogenic influence of "'ivory tower' syndrome" (Toffel 2016, p. 1494). They became readily capable of bridging the arguably unbridgeable gap between scientific rigor and practical relevance, and taming the seemingly intractable problems of "knowledge production" and "knowledge transfer" (Sandberg and Tsoukas 2011, p. 338), all of which have been and remain to be persistent concerns in both circles of ecological practice and science in the modern-day world (Xiang 2017, p. xi). As such, their ecophronetic way of conducting practice research manifested itself in a myriad of ecological projects and public policy instrument that has been providing lasting ES benefits to the human beings across generations (For a recently documented archive of exemplary instances of ecophronetic practice research, see a 2016 special ecological wisdom issue in the journal Landscape and Urban Planning, volume 155).

As an intellectual and character asset, ecophronesis has been and continues to be an unparalleled source of inspiration for ecological scholar-practitioners to mindfully engage themselves in ecophronetic practice research in Pasteur's quadrant (Wang and Xiang 2016; Xiang 2017). It promises to be equally inspirational to members of the ES scholarly community for ecophronetic ES research.

\section{Pasteur's quadrant as an appealing alternative}

Besides the master skill par excellence of ecophronesis, what else will it take for ES scholars to be willing to choose, and able to position themselves in, Pasteur's quadrant in particular instances of research as they see fit? Since neither enacting the role of scholar-practitioner nor conducting ecophronetic ES research can take place in a vacuum, this and other practical questions pertaining to making role choices certainly 
merit attention. Instead of the cliché "it takes a village", specific insights into such pragmatic matters as funding, publication, scholarship, membership in the scholarly community, and even career development will undoubtedly enable ES scholars to make more informed and prudent choices (For an initial account on some of these matters in a broader context, see Wasserman and Kram 2009). Furthermore, addressing practical questions of this kind should also be an integral part of ES scholarly inquiry because, according to American philosopher of science Thomas Kuhn, any "analysis of the development of scientific knowledge must take account of the way science has actually been practiced." (Kuhn 1970, p. 11, italic added) Only can this quest for useful insights take place, however, when the ES scholarly community providently considers embracing the role of scholarpractitioner and celebrating the stand of ecophronetic ES research. This prospect of helping open new research frontiers indeed makes Pasteur's quadrant an even more appealing alternative.

Acknowledgements The research and writing activities pertaining to this essay are supported in part by China National R \& D Program entitled" Building strong ecological security patterns through elevating green infrastructure's level of ecosystem services" (No. 2017YFC0505705).

\section{References}

Albert C, Aronson J, Fürst C, Opdam P (2014) Integrating ecosystem services in landscape planning: requirements, approaches, and impacts. Landscape Ecol 29(8): $1277-1285$

Artmann M, Bastian O, Grunewald K (2017) Using the concepts of green infrastructure and ecosystem services to specify leitbilder for compact and green cities-the example of the landscape plan of Dresden (Germany). Sustainability 9:198. doi:10.3390/su9020198

Baró F, Gómez-Baggethun E, Haase D (2017) Ecosystem service bundles along the urban-rural gradient: insights for landscape planning and management. Ecosyst Serv 24:147-159

BenDor TK, Spurlock D, Woodruff SC, Olander L (2017) A research agenda for ecosystem services in American environmental and land use planning. Cities 60:260-271

Churchman CW (1967) Wicked problems. Manag Sci 14(4):B141-B142

Cook BR, Spray CJ (2012) Ecosystem services and integrated water resource management: different paths to the same end? J Environ Manag 109:93-100

Costanza R, De Arge R, De Groot R, Farber S, Grasso M, Hannon B, Limburg K, Naeem S, O’neill RV, Paruelo J,
Raskin RG (1997) The value of the world's ecosystem services and natural capital. Nature 387(6630):253-260

Daily GC (1997) Nature's services: societal dependence on natural ecosystems. Island Press, Washington, D.C

Egoh B, Reyers B, Rouget M, Richardson DM, Le Maitre DC, van Jaarsveld AS (2008) Mapping ecosystem services for planning and management. Agr Ecosyst Environ 127:135-140

Haase D, Larondelle N, Andersson E, Artmann M, Borgström S, Breuste J, Gomez-Baggethun E, Gren $\AA$, Hamstead Z, Hansen R, Kabisch N (2014) A quantitative review of urban ecosystem service assessments: concepts models, and implementation. Ambio 43(4):413-433

Hansen R, Frantzeskaki N, McPhearson T, Rall E, Kabisch N, Kaczorowska A, Kain JH, Artmann M, Pauleit S (2015) The uptake of the ecosystem services concept in planning discourses of European and American cities. Ecosyst Serv 12:228-246

Head BW, Xiang W-N (2016) Why is an APT approach to wicked problems important? Landsc Urban Plan 154:4-7

Johnson P (1992) The birth of the modern: world society 1815-1830. Harper Perennial, New York

Kremer P, Hamstead Z, Haase D, Frantzeskaki N, Andersson E, Kabisch N, Larondelle N, Rall E, Voigt A, Baró F (2016) Key insights for the future of urban ecosystem services research. Ecol Soc 21(2):29

Kuhn, T.S. 1970. Logic of discovery or psychology of research? In: Curd, M. and Cover, J.A. eds. (1998). Philosophy of Science: The Central Issues. New York, W.W. Norton \& Company, pp. 11-19 [From Lakatos, I. and Musgrave, A. eds. (1970). Criticism and the Growth of Knowledge. Cambridge, UK, Cambridge University Press, pp. 4-10]

Langemeyer J, Gomez-Baggethun E, Haase D, Scheuer S, Elmqvist T (2016) Bridging the gap between ecosystem service assessments and land-use planning through multicriteria decision analysis (MCDA). Environ Sci Policy 62:45-56

Luederitz C, Brink E, Gralla F, Hermelingmeier V, Meyer M, Niven L, Panzer L, Partelow S, Rau AL, Sasaki R, Abson DJ (2015) A review of urban ecosystem services: six key challenges for future research. Ecosyst Serv 14:98-112

MacDonald DH, Bark RH, Coggan A (2014) Is ecosystem service research used by decision-makers? A case study of the Murray-Darling Basin. Australia. Landscape Ecology 29(8): 1447-1460

McHarg IL (1969) Design with nature. Doubleday/Natural History Press, Garden City

Sandberg J, Tsoukas H (2011) Grasping the logic of practice: theorizing through practical rationality. Acad Manag Rev 36(2):338-360

Schnadelbach, R.T. 2001. Ian McHarg 1920- In: Palmer, J.A., Cooper, D.E., and Corcoran, P.E. (eds.). Fifty Key Thinkers on the Environment. London: Routledge. pp. 228-241

Schön, D. 2001. The crisis of professional knowledge and the pursuit of an epistemology of practice. Chapter 13, in Competence in the Learning Society, Raven, J., \& Stephenson, J. (Eds), 185-207. Reproduced on the HE Academy website by kind permission of Peter Lang Publishing, Inc. Retrieved online from http://wwwnew1. heacademy.ac.uk/assets/documents/resources/heca/heca_ c113.pdf 
Smith GJ, Schmidt MM, Edelen-Smith PJ, Cook BG (2013) Pasteur's quadrant as the bridge linking rigor with relevance. Except Child 79(2):147-161

Steiner F (2004) Healing the earth: the relevance of Ian McHarg's work for the future. Philos Geogr 7(1):141-149

Steiner F (2016) The application of ecological knowledge requires a pursuit of wisdom. Landsc Urban Plan 155:108-110

Stokes DE (1997) Pasteur's quadrant: basic science and technological innovation. Brookings Institution Press, Washington, D.C.

Stringer ET (2014) Action research (edition 4). Sage, Los Angeles

Toffel MW (2016) Enhancing the practical relevance of research. Product Oper Manag 25(9):1493-1505

Wang XH, Xiang W-N (2016) Ecological wisdom for urban sustainability: doing real and permanent good in ecological practice. Landsc Urban Plan 155:1-2

Wasserman IC, Kram KE (2009) Enacting the scholar-practitioner role: an exploration of narratives. J Appl Behav Sci 45(1):12-38
Woodruff SC, BenDor TK (2016) Ecosystem services in urban planning: comparative paradigms and guidelines for high quality plans. Landsc Urban Plan 152:90-100

Wu JG (2006) Landscape ecology, cross-disciplinarity, and sustainability science. Landscape Ecol 21:1-4

Xiang W-N (2013) Working with wicked problems in socioecological systems: awareness, acceptance, and adaptation. Landsc Urban Plan 110(1):1-4

Xiang W-N (2014) Doing real and permanent good in landscape and urban planning: ecological wisdom for urban sustainability. Landsc Urban Plan 121:65-69

Xiang W-N (2016) Ecophronesis: the ecological practical wisdom for and from ecological practice. Landsc Urban Plan 155:53-60

Xiang W-N (2017) Forward II: In greening cyborg cities, be an ecophronetic scholar-practitioner. In: Tan PY, Jim CY (eds) 2017. Forms and functions. Singapore, Springer Nature. pp.ix-xiv, Greening cities

Yang B, Li SJ (2016) Design with Nature: Ian McHarg's ecological wisdom as actionable and practical knowledge. Landsc Urban Plan 155:1-10 